\title{
THE ISOPOD CRUSTACEAN ACANTHONISCUS SPINIGER KINAHAN REDESCRIBED.
}

\author{
By Harriet Richardson,
}

Collaborator, Division of Larine Invertebrates, U. S. National Museum.

In 1847 Adam White ${ }^{a}$ gave the name Acanthoniscus spiniger to a new Isopod which Mr. Philip H. Gosse found in Jamaica. This form was not described at that time. Six years afterward the latter naturalist ${ }^{b}$ referred in the following way to this isopod: "A curious little dark grey Oniscus, every segment of which is armed with two spines, was numerous; it has been described by my friend, Mr. Adam White of the British Museum, under the name of Acanthoniscus spiniger." The first description which was published of Acanthoniscus spiniger was that of Kinahan in 1859. ${ }^{c}$ Kinahan's description is based on the original specimen in the British Museum, which was the only specimen he had seen. In 1885 Budde-Lund ${ }^{d}$ placed in his family Onisci the genus Acanthoniscus of which he said : Ad tribum Oniscorum sequentia genera in natura mihi ignota pertinere videntur." He had evidently not seen the specimen in the British Museum for he gives no description, and although he does not place the genus in either section I, Armadilloidea, or section II, Oniscoidea, yet he refers to it at the end of his section Oniscoidea. Kinahan did not place the genus in any family.

About 1877 Mr. H. G. Hubbard, the entomologist, made collections in Jamaica. Some of his collections were given to the Museum of Comparative Zoology and some came to the U. S. National Museum after his death. Among the insects was a specimen of Acanthoniscus spiniger, which was turned over to me last winter. The label accompanying it reads: "Oniscus spiniger. Jamaica." As I had not seen a specimen of this species before, and as the only description of it is that given by Kinahan, I thought it would be of interest to

\footnotetext{
${ }^{a}$ List Crust. Brit. Mus., 1847, p. 99.

${ }^{b}$ A Naturalist's Sojourn in Jamaica, 1851, p. 65.

${ }^{c}$ Proc. Dublin University, I, 1859, p. 197, pl. 19, fig. 4.

${ }^{d}$ Crust. Isop. Terrestria, 1885, p. 242.
} 
redescribe and figure it. No general figure has ever been given, although Kinahan gave detailed drawings of the uropod and the terminal abdominal segment. It seems strange that, although this

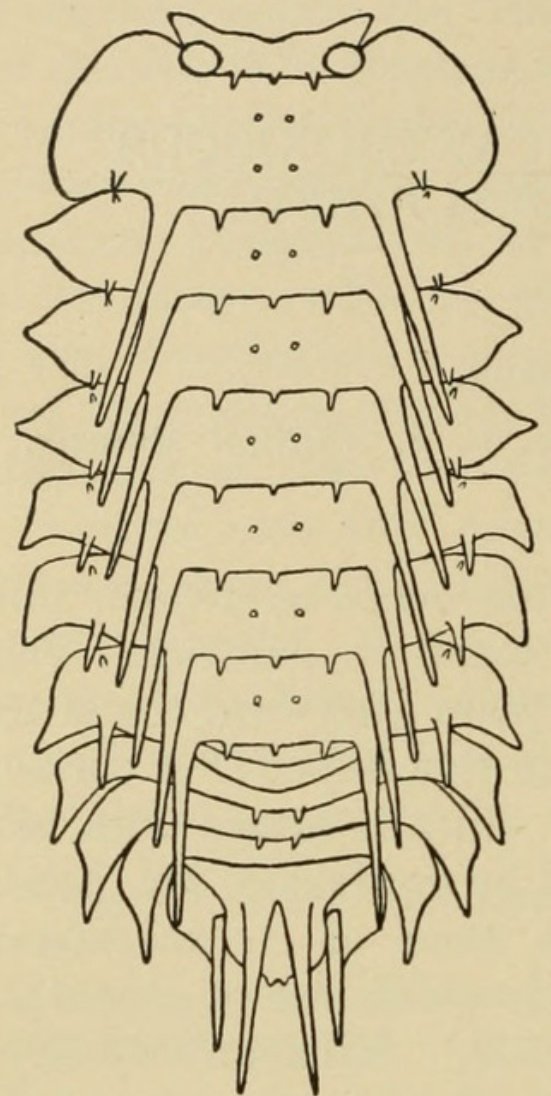

Fig. 1.- - CANTHONiscus Spiniger. isopod is said to be numerous in Jamaica, no specimens exist, so far as I know, in any museum except the British Museum.

Family ARMADILLIDIDA.

\section{ACANTHONISCUS Kinahan.}

Acanthoniscus Kinahan, Proc. Dublin University, I, 1859, p. 197.

\section{ACANTHONISCUS SPINIGER Kinahan.}

Acanthoniscus spiniger White (nomen nudum), List Crust. Brit. Museum, 1847, p. 99.-Gosse, A Naturalist's Sojourn in Jamaica, 1851, p. 65.Kinahan, Proc. Dublin University, I, 1859 , p. 197 , pl. 19 , fig. 4.-BuddeLund, Crust. Isop. Terrestria, 1885, pp. 241-242.-Richardson, Bull. U. S. Nat. Mus., No. 54, 1905, pp. 637-638, 592 footnote.

Body oblong ovate, capable of rolling up into a ball. Color, in alcohol, dark brown, with irregular spots of light brown.

Head much wider than long, with the front emarginate and the lateral angles acutely produced. The eyes are large, bulbous, composite, and situated at the post-lateral angles of the head. On the posterior margin of the head are three spines, one in the median line and one on either side, close to the eye, the median spine being smaller than the other two. The first pair of antenna are rudimentary and inconspicuous. The second pair are broken and the flagellum lost. The first article of the peduncle is short; the second and third are long and subequal; the fourth is one and a half times longer than the third; the fifth is about one and a half times longer than the fourth.

The first segment of the thorax is longer than any of those following. The lateral

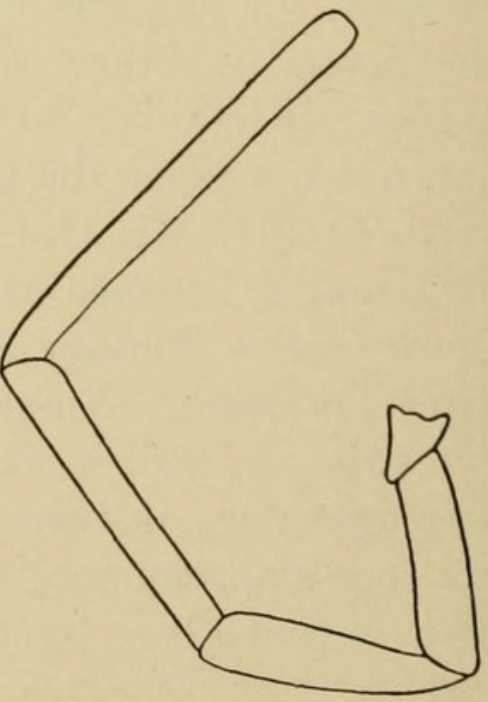

Fig. 2.-ACANTHONiscus SPINIger. Second antenna. $\times 23$. (Flagellum LOST.) parts are produced in large, rounded processes, which extend downward and upward, surrounding the posterior portion of the head. This segment is armed with two extremely long spines, one on either 
side, which are nearly three times the length of the segment. Between these two spines are three short ones on the posterior margin, one being in the median line. Anterior to these spines are four small tubercles, two on either side of the median line in longitudinal series. Lateral to the long spine, halfway between it and the lateral margin, is one small spine on either side. The six following segments are about equal in length. Each is armed with two extremely long spines, one on either side of the body. Between these long spines are three small spines on the posterior margin, one in the median line. Anterior to these spines are two small tubercles, one on either side of the

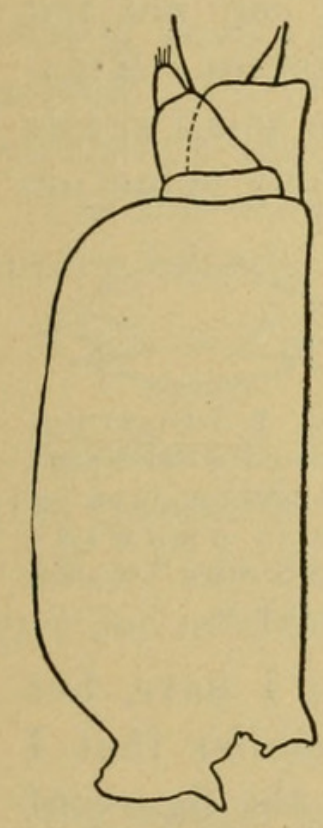

Fig. 4.-ACANTHONIS CUS SPINIGER. M A X I L I I P E D. $\times 27 \frac{1}{3}$. median line. Lateral to these spines are two small ones, half-

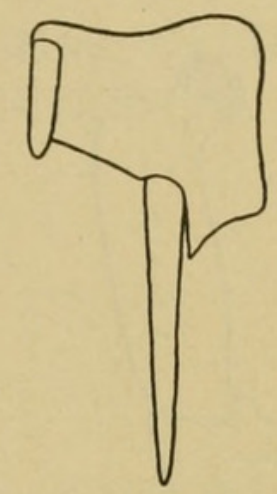

Fig. 3.-ACANTHONISCUS SPINIGER. UROPOD. (UNDER SIDE.) way between them and the lateral margin, one small anterior one and a posterior one, which gradually increases in length, that on the seventh segment being about half as long as the longest spine.

The first two segments of the abdomen have the lateral parts covered by the last thoracic segment. The lateral parts of the three following segments are greatly produced, the posterior angles being acute. These five segments are about equal in length; the third and fourth are armed with two small spines on the posterior margin, one on either side of the median line. The sixth, or terminal segment, is widest at the base, contracted about the middle with the posterior half widely rounded and notched in the middle, a small triangular process on either side of the notch. On the anterior portion of the segment are two long spines, equal in length to twice the length of the segment, placed one on either side of the median line. The peduncle of the uropoda resembles in form the lateral parts of the third, fourth and fifth thoracic segments; the inner pos-

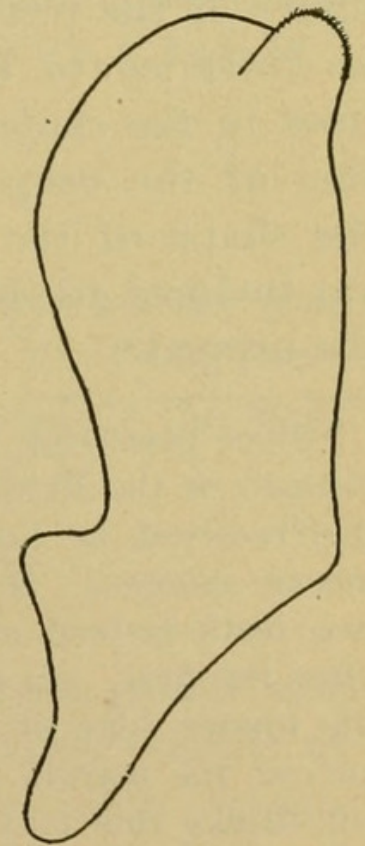

Fig. 5. - AcanthonI S C U S SPINIGER. Second Maxilla. $\times 77 \frac{1}{2}$. terior angle is acutely produced, the outer angle being rounded. The inner branch is inconspicuous in a dorsal view, being concealed beneath the abdomen; it is attached at the inner anterolateral angle of the peduncle and does not quite reach the tip of

Proc. N. M. vol. xxxvi-09-2S 
the abdomen. The outer branch is produced in a long spine, extending half its length beyond the inner posterior angle of the

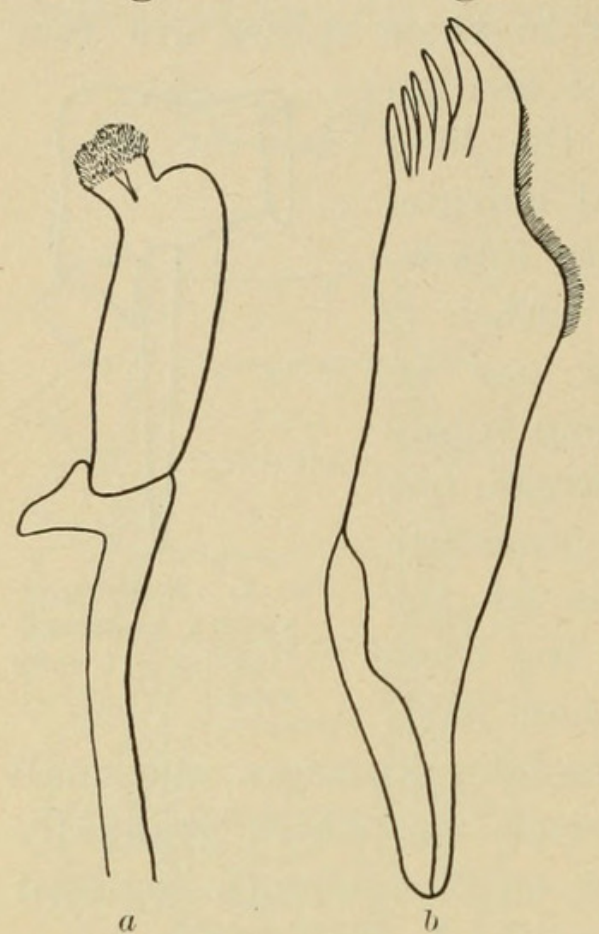

Fig. 6.-Acanthoniscus SPINiger. First Maxilla. a. InNer Lobe.

b. Outer lobe. $\times 77 \frac{1}{2}$. peduncle; in a dorsal view it is inserted on the inner lateral margin at the anterior angle.

An anterior view of the head shows the labrum produced on either side so as to extend much beyond the epistome. The inner lamella of the first maxillæ carries two plumose processes.

Although this specimen does not agree in every respect with the description of Kinahan, I can not but think it is the same species. Kinahan does not mention the small spines placed between the two long spines on the posterior margin of the thoracic segments. He also does not mention the presence of spines on the abdomen, but in his figure of the terminal abdominal segment I think he intended to represent them in the two long lines in the center of his figure. His representa-

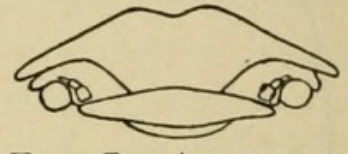

FIG. 7.-ACANTHONI S C U S SPINIGER. ANTERIOR VIEW OF HEAD S H O W I N G EPISTOME W I T H LABRU M. tion of the uropod does not agree with the specimen I have, but the shape of the terminal abdominal segment is so similar that I am inclined to think that there must be some error in the figure of the uropod. ${ }^{a}$

${ }^{a}$ Since preparing the above description I sent a copy of my figure to Doctor Calman of the British Museum for comparison with the type. In his answer, just received, he says that he is almost certain that my specimen is Acanthoniscus spiniger. He mentions the fact that in the type-specimen there are two teeth instead of three on the posterior margin of the thoracic segments after the first. On the first segment, the middle tooth is extremely small. On the hinder edge of the head are only two teeth, placed a little in front of, not on, the margin. He also noticed a difference in the shape of the uropod, but thinks this may be due to its being in a slightly different position from my sketch. He very kindly made drawings of the type for me. Although I am aware of these discrepancies, I hesitate to consider my specimen other than Acanthoniscus spiniger when the resemblance is so strong and the locality the same. Moreover the type-specimen is probably a dried specimen and some allowance must be made for change in contour owing to its condition. When Kinahan described it, twelve years after it was collected, it was probably in no better condition than it is now, 


\section{$2 \mathrm{BHL}$ Biodiversity Heritage Library}

Richardson, Harriet. 1909. "The isopod crustacean Acanthoniscus spiniger Kinahan redescribed." Proceedings of the United States National Museum 36(1678), 431-434. https://doi.org/10.5479/si.00963801.36-1678.431.

View This Item Online: https://www.biodiversitylibrary.org/item/53526

DOI: https://doi.org/10.5479/si.00963801.36-1678.431

Permalink: https://www.biodiversitylibrary.org/partpdf/52553

\section{Holding Institution}

Smithsonian Libraries

\section{Sponsored by}

Smithsonian

\section{Copyright \& Reuse}

Copyright Status: Public domain. The BHL considers that this work is no longer under copyright protection.

This document was created from content at the Biodiversity Heritage Library, the world's largest open access digital library for biodiversity literature and archives. Visit BHL at https://www.biodiversitylibrary.org. 